3. Бессонова В. П., Козюкина Ж. Т., Лыюенко И. И. Влияние избытка микроэлементов и двуокиси серы на световые реакции фотосинтеза в хлоропластах гороха // Физиология и биохимия культ. растений. 1990. 22. № 3. С. 220-225.

4. Зурнаджи T. Г., Пельтіхіна P. I. Адаптивні можливості деяких квітково-декоративних рослин в умовах техногенного середовища // Укр. ботан. журн. 1997. Т. 54. № 1. C. $68-70$.

5. Приседский Ю.Г., Максимов В.М. Влияние загрязнения среды соединениями фтора, серы и азота на ростовые процессы проростков робинии псевдоакации // Промышленная ботаника: состояние и перспективы развития: материалы Третьей Междунар. науч. конф. (Донецк, 3-5 сентября 1998 г.). Донецк. 1998. С. 289-291.

6. Приседський Ю. Г. Програми статистичної обробки експериментальних даних. Донецьк. 2000. 15 с.

7. Приседський Ю. Г. Статистична обробка результатів біологічних експериментів. Донецьк. 1999. 210 с.

8. Тарабрин В. П., Кондратюк Е. Н., Башкатов В. Г. и др. Фитотоксичность органических и неорганических загрязнителей. Киев. 1986. 216 с.

9. Environmental monitoring of fluoride emission using precipitation, dust, plant and soil samples /J. Franzaring at al. //Environmental Pollution. 2006. Vol. 144. N 1. P. 158-165.

10. Glick B. R. Phytoremediation: synergistic use of plants and bacteria to clean up the environment // Biotechnology Advances. 2003. Vol. 21. N 5. P. 383-393.

Надійшла до редколегії 29.07.2016 p.

Н. О. Рощина

НДІ біології Дніпропетровського начіонального університету

імені Олеся Гончара

\title{
ФЛОРОЦЕНОТИЧНЕ РІЗНОМАНІТТЯ ОЗЕР ПРИСАМАР'Я У ПОРІВНЯННІ ЗІ ШТУЧНИМИ ВОДОЙМАМИ
}

Представлено результати досліджень флори водойм долини р. Самари. Наведено список та проведено аналіз водної флори та ценозів озер та штучних водойм. Найбільшим флороценотичним різноманіттям відрізняються водойми заплави та арени ріки Самари, найменшим - штучні водойми. Це пов'язано зі ступенем антропогенного впливу, а також гідрологічними та геоморфологічними особливостями умов існування видів.

Ключові слова: флора, рослинність, озера, ставки, антропогенний вплив.

\section{Н. О. Рощина}

НИИ биологии Днепропетровского национального университета имени Олеся Гончара

\section{ФЛОРОЦЕНОТИЧЕСКОЕ РАЗНООБРАЗИЕ ОЗЕР ПРИСАМАРЬЯ В СРАВНЕНИИ С ИСКУССТВЕННЫМИ ВОДОЕМАМИ}

Освещены результаты исследований флоры водоемов долины р. Самары. Представлен список и проведен анализ водной флоры и ценозов озер и искусственных водоемов. Наибольшим флороценотическим разнообразием отличаются водоемы поймы и арены реки Самары, наименьшим - искусственные водоемы. Это связано со степенью антропогенного влияния, а также гидрологическими и геоморфологическими особенностями условий существования видов.

Ключевые слова: флора, растительность, озера, пруды, антропогенное влияние.

(C) Н. О. Рощина, 2016 


\section{N. O. Roschina \\ Research Institute of biology Oles Gonchar Dnepropetrovsk National University \\ FLORACENOTIC DIVERSITY PRISAMARYA'S LAKES IN COMPARSION WITH ARTIFICIAL REVISIORS}

Research carried out in standing water habitats Samara River. Standing water bodies include natural lake (floodplain lakes, arenas lakes and lakes of terraces III) and artificial water bodies (ponds, subsidental ponds, sumps). Materials own research (2006-2013 years) are presented in this work. Archival (herbarium) and literature data were included, too. Comparative analysis florotsenotic variety of water bodies was conducted. Reservoirs of a flood plain and arena of the Samara River differ the greatest phytodiversity. The flora of artificial revisiors is characterized by the smallest variety. It is connected with degree of atropology influens and hydrological and geomorphological features of existence conditions of species. Among the plants that form communities, the largest number in the floodplain (39 species) and Arena (26 species). In lakes saline terraces and artificial lakes, nearly all species form communities. Arealolohichnyy analysis showed that most aquatic plants, almost equal numbers refer to the Eurasian (15) holarktyc (14) types of habitat or are cosmopolitans (12). Floodplain and arenas Prysamar'ya lakes can be considered the gene pool of rare and endangered species of water plants Steppe Dnieper.

Keywords: flora, vegetation, lakes, ponds, anthropogenic influence.

Озера, як гідрологічний тип водойм (екосистем), у межах степової зони розташовані на території долино-терасових ландшафтів, які менш за все трансформовані господарчою діяльністю.

Згідно із Законом України «Про рослинний світ» та ратифікацією міжнародної Конвенції про біорізноманіття, проводиться створення Державного кадастру рослинного світу України. Це обумовлює необхідність виявлення сучасного флористичного та ценотичного стану рослинного покриву мілководь озер Північного Степового Придніпров'я та проведення аналізу їх динаміки та антропогенної трансформації. В більшості своїй озера є акваторіями з високим біорізноманіттям та резерватами рідкісних і зникаючих видів макрофітів, що має стати підставою для проведення заходів збереження їх різноманіття.

Матеріали та методи. В долині р. Самари стоячі водойми представлені природними озерами (заплавні озера, аренні озера та озера III тераси) та штучними водоймами (водосховища, ставки, відстійники).

Порівняльний аналіз флороценотичного різноманіття озер та штучних стоячих водойм було проведено на основі власних досліджень (2006-2013 років) під час маршрутних, напівстаціонарних та стаціонарних досліджень, а також літературних та архівних матеріалів (НДІ біології та інституту Дніпродіпроводгосп).

Матеріали щодо характеристики компонентів екосистем району дослідження зустрічаються в наукових публікаціях починаючи з 1889 року $[1-9,11 ; 13 ; 14$; $16 ; 18 ; 21-23]$.

Флористичні дослідження проводилися з використанням загальноботанічних методів збору, гербаризації [20] та визначення видів [12; 19; 26; 27] та спеціальних гідроботанічних методів [17]. Для відбору занурених та плаваючих макрофітів використовувалася «кішка» модифікації О. В. Свдущенка.

Біоекологічну характеристику видів надано за системою екоморф О.Л. Бельгарда [10]. Назви видів наведено за сучасною ботанічною номенклатурою [29].

Фізико-географічні умови басейну р. Самари, в яких знаходяться озера і штучні водойми, мають кліматичні [25], грунтові [24] та гідрологічні особливості [15].

Результати та їх обговорення. Самара має розгалужену гідрографічну мережу з 39 притоками першого порядку (більше 10 км), 142 притоками другого, третього та інших порядків і густотою річкової мережі (з урахуванням приток) 0,33 км/км ${ }^{2}[15]$. 
Озера розташовані переважно на території заплави основної ріки басейну Самари, в ії середній (від впадіння р. Бик до впадіння р. Вовча), нижній (від впадіння р. Вовча до м. Новомосковськ) та пригирловій підтопленій частині.

Озероподібні штучні водойми включають 71 водосховище, більше 100 ставків, які розповсюджені по усій території басейну. В середній частині Самари зосереджено штучні просадочні водойми (утворені внаслідок шахтних виробок) та відстійники шахтних вод гірничого комплексу Західного Донбасу.

Видовий склад рослинності стоячих водойм Присамар'я включає 57 видів, що належать до 26 родин (табл.), з яких 16 - рідкісні та зникаючі види різного охоронного статусу [28].

Розподіл угруповань рослинності водойм також різноманітний.

У водоймах заплави рослинний покрив представлено зональним типом заростання. Основу складають угруповання рогоза вузьколистого, кушира зануреного з участю ряски триборозенчастої з наводним ярусом жабурника звичайного та ряски малої.

Тут знайдено рідкісні для Степового Придніпров'я угруповання рдесника плаваючого та плавушника болотного і зареєстровано також рідкісні види: реліктовий червонокнижний вид - кушир донський, та представник печіночних мохів - річчіокарп плавучий.

Озера, які розташовані в лісових біогеоценозах, більш зарослі повітряно-водяною рослинністю або угрупованнями болотної рослинності: осоки берегової та пухирчастої, очерета з рогозом вузьколистим та широколистим з ярусом жабурника та ряски маленької, а також підводного ярусу кушира зануреного з ряскою триборозенчастою.

Озера арени переважно подібні до прируслових. Іноді тут зустрічається пухирчатка мала - рідкісний для Степового Придніпров’я вид. У центральній частині водойм або на ділянках, які приєднуються до зони гелофітів 3 глибини, по типу розсіяно-плямистого заростання розповсюджені фітоценози латаття білого та водяного різака алоеподібного. У деяких озерах зрідка трапляється червонокнижний вид альдрованда пухирчаста - дуже рідкісний для Степового Придніпров'я. Тут є невеликі болота зі сфагновими мохами, котрі знаходяться на південній межі свого ареалу на території України. Раніше вони були значно поширені і досягали пригирлової частини Самари.

Озера солончакової тераси в деяких рисах подібні заплавним, але відрізняються наявністю ряду галофільних видів. Тут, в озері Булахівський лиман розповсюджені ценози типово морського виду судинних рослин - Ruppia maritima L. [8].

Флора та рослинність просадочних водойм значно бідніша (табл.).

На мілководдях ставків на глибинах до 1 м сформувалися асоціації повітряно-водних рослин: очерету південного (Phragmites australis); рогозу вузьколистого (Typha angustifolia), рогізу широколистого (Турha latifolia).

До їх складу звичайно входять принаймні: омег водяний (Oenantae aquatica), сусак зонтичний (Butomus umbellatus), частуха подорожникова (Alisma plantagoaquatica).

У верхів'ях ставків зона повітряно-водяних рослин розширюється у вигляді дельти і вище продовжується по водотоку.

На глибинах більше 1 м розповсюджено ценози зануреної рослинності: рдесника кучерявого (Potamogeton crispus), кушира зануреного (Ceratophyllum demersum), рдесника гребінчастого (Potamogeton pectinatus), водяного жовтецю волосолистого (Batrachium trichophyllum) з участю ряски триборозенчастої (Lemna trisulca L).

Мілководні зони відстійників майже позбавлені водної рослинності, лише в деяких 3 них мають місце мікроассоцації очерету південного та бульбокомишу морського. 
Різноманіття флороценотичного складу водойм відображає як природні умови водойм, так і рівень їх антропогенної трансформації. Екоморфи розташовані за ступенем важливості екологічних факторів (табл.).

Таблиия

Біоекологічна характеристика та розповсюдження видів і ценозів

\begin{tabular}{|c|c|c|c|c|c|c|c|}
\hline Види в межах родин & 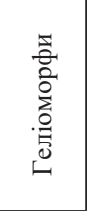 & 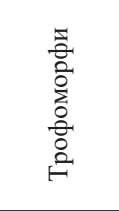 & 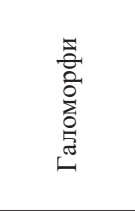 & 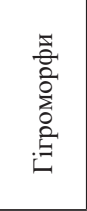 & 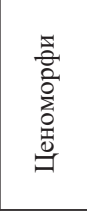 & 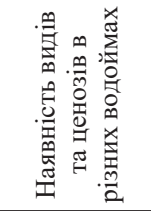 & $\begin{array}{l}\text { 悹 } \\
\text { 芯 } \\
\text { 㐭 } \\
\text { ம }\end{array}$ \\
\hline $\begin{array}{l}\text { Alismataceae } \\
\text { Alisma plantago-aquatica L. }\end{array}$ & $\mathrm{He}$ & $\mathrm{MgTr}$ & FHal & Hel & $\mathrm{Aq}$ & $\frac{3 \mathrm{ACCT}}{3 \mathrm{C}}$ & голар. др.ср. \\
\hline Sagittaria sagittifolia L. & $\mathrm{He}$ & $\mathrm{OgMg}$ & Dul & Hel & $\mathrm{Aq}$ & $\frac{3 \mathrm{~A}}{3 \mathrm{~A}}$ & євраз. др.ср. \\
\hline $\begin{array}{l}\text { Apiaceae } \\
\text { Oenanthe aquatica (L.) Poir. }\end{array}$ & $\mathrm{He}$ & $\operatorname{MgTr}$ & FHal & $\mathrm{Hg}$ & Pal & $\frac{3 \mathrm{ACCT}}{3 \mathrm{AC}}$ & євраз \\
\hline $\begin{array}{l}\text { Siella erecta (Huds.) } \\
\text { M.Pimen. }\end{array}$ & $\mathrm{He}$ & $\operatorname{MsTr}$ & DulCar & $\mathrm{Hg}$ & Pal & $\underline{3}$ & євр.в. др.ср. \\
\hline Sium latifolium L. & $\mathrm{HeSc}$ & $\mathrm{MsTr}$ & FHalCa & $\mathrm{Hg}$ & Pal & $\frac{3 \mathrm{~A}}{3}$ & євраз.др. ср. \\
\hline Sium sisaroideum DC. & $\mathrm{HeSc}$ & $\operatorname{MgTr}$ & FHal & $\mathrm{Hg}$ & Pal & $\frac{3 C}{3}$ & європ. др.ср. \\
\hline $\begin{array}{l}\text { Araceae } \\
\text { Acorus calamus L. }\end{array}$ & $\mathrm{He}$ & $\operatorname{MgTr}$ & FHal & Hel & $\begin{array}{c}\text { Aq } \\
\text { Adv }\end{array}$ & $\frac{3 \mathrm{~A}}{3}$ & євраз. \\
\hline $\begin{array}{l}\text { Butomaceae } \\
\text { Butomus umbellatus L. }\end{array}$ & $\mathrm{He}$ & $\operatorname{MgTr}$ & FHal & $\mathrm{He}$ & $\mathrm{Aq}$ & $\frac{3 \mathrm{AC}}{3}$ & др.ср. \\
\hline $\begin{array}{l}\text { Callitrichaceae } \\
\text { Callitriche palustris L. }\end{array}$ & $\mathrm{HeSc}$ & $\operatorname{Mg} \operatorname{Tr}$ & Dul & Hyr & $\mathrm{Aq}$ & $\underline{3}$ & голар. др.ср. \\
\hline $\begin{array}{l}\text { Cerathophyllaceae } \\
\text { Cerathophyllum } \\
\text { demersum L. }\end{array}$ & $\mathrm{Sc}$ & $\mathrm{MgTr}$ & FHal & Hy er & $\mathrm{Aq}$ & $\frac{\text { ЗАССтП }}{\text { ЗАССтП }}$ & голар. др.ср. \\
\hline $\begin{array}{l}\text { Cerathophyllum } \\
\text { pentacanthum Hainald }\end{array}$ & $\mathrm{HeSc}$ & MsTr & Bas.Neit & Hy er & $\mathrm{Aq}$ & $\frac{3}{3}$ & євраз \\
\hline $\begin{array}{l}\text { Cerathophyllum } \\
\text { submersum L. }\end{array}$ & $\mathrm{HeSc}$ & MsTr & Bas.Neit & Hy er & $\mathrm{Aq}$ & $\frac{3}{3}$ & євраз \\
\hline $\begin{array}{l}\text { Cerathophyllum tanaiticum } \\
\text { Sapieg. }\end{array}$ & $\mathrm{HeSc}$ & $\operatorname{MgTr}$ & $\mathrm{Du}$ & Hy er & $\mathrm{Aq}$ & $\underline{3}$ & євраз \\
\hline $\begin{array}{l}\text { Cyperaceae } \\
\text { Bolboschoenus } \\
\text { maritimus (L.) Palla } \\
\end{array}$ & $\mathrm{He}$ & $\mathrm{Og} \operatorname{Tr}$ & FHal & $\mathrm{HeHg}$ & AqPal & $\frac{\text { ЗАССтПВ }}{\text { ЗАССтПВ }}$ & голар. др.ср. \\
\hline Scirpus lacustris L. & $\mathrm{He}$ & $\operatorname{MsMgTr}$ & FHal & Hel & $\mathrm{Aq}$ & $\frac{\text { ЗАССтП }}{\text { ЗАССтП }}$ & евраз др.ср. \\
\hline $\begin{array}{l}\text { Scirpus tabernaemontani } \\
\text { C.C.Gmel. }\end{array}$ & $\mathrm{He}$ & $\operatorname{MsMgTr}$ & Hal & $\mathrm{He}$ & $\mathrm{Aq}$ & $\frac{3 \mathrm{AC}}{3 \mathrm{AC}}$ & $\begin{array}{c}\text { голар. } \\
\text { з.др.cp. }\end{array}$ \\
\hline $\begin{array}{l}\text { Droseraceae } \\
\text { Aldrovanda vesiculosa } L \text {. }\end{array}$ & $\mathrm{HeSc}$ & $\operatorname{MgTr}$ & Dul & $\mathrm{Pl}$ & $\mathrm{Aq}$ & $\underline{\mathrm{A}}$ & косм. \\
\hline $\begin{array}{l}\text { Elatinaceae } \\
\text { Elatine alsinastrum L. }\end{array}$ & $\mathrm{ScHe}$ & $\mathrm{MsTr}$ & Dul & $\mathrm{Hg}$ & PalAq & $\frac{3}{3}$ & євраз \\
\hline $\begin{array}{l}\text { Haloragaceae } \\
\text { Myriophyllum spicatum L. }\end{array}$ & $\mathrm{HeSc}$ & $\operatorname{MgTr}$ & FHalCa & Hyr & $\mathrm{Aq}$ & $\frac{3 \mathrm{AC \Pi}}{3 \mathrm{AC \Pi}}$ & голар. др.ср. \\
\hline $\begin{array}{l}\text { Myriophyllum } \\
\text { verticillatum L. }\end{array}$ & $\mathrm{HeSc}$ & MgTrr & DulNit & Hyr & $\mathrm{Aq}$ & $\underline{\mathrm{A}}$ & косм. \\
\hline $\begin{array}{l}\text { Hydrocharitaceae } \\
\text { Elodea canadensis Michx. }\end{array}$ & $\mathrm{HeSc}$ & $\operatorname{MgTr}$ & DulCa & Hyr & $\mathrm{Aq}$ & $\underline{3 \mathrm{~A}}$ & геми. \\
\hline Hydrocharis morsus-ranae L. & $\mathrm{HeSc}$ & $\operatorname{MgTrr}$ & DulNit & Pler & $\mathrm{Aq}$ & $\frac{3 \mathrm{ACC} \Pi}{3 \mathrm{AC} \Pi}$ & євраз. др.ср. \\
\hline Stratiotes aloides $L$. & $\mathrm{He}$ & $\operatorname{MgTr}$ & Dul AcCa & Hyr & $\mathrm{Aq}$ & $\frac{3 \mathrm{~A}}{3 \mathrm{~A}}$ & європ. др.ср. \\
\hline $\begin{array}{l}\text { Lemnaceae } \\
\text { Lemna gibba L. }\end{array}$ & $\mathrm{HeSc}$ & $\operatorname{MsMgTr}$ & FHal & Pl er & $\mathrm{Aq}$ & $\underline{3 \mathrm{~A}}$ & косм. \\
\hline
\end{tabular}


Продовження табл.

\begin{tabular}{|c|c|c|c|c|c|c|c|}
\hline Види в межах родин & 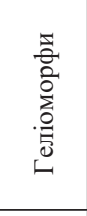 & 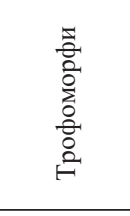 & 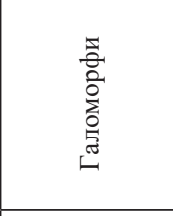 & 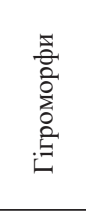 & 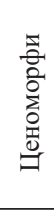 & 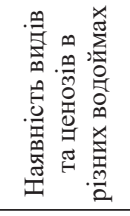 & $\begin{array}{l}\text { 屁 } \\
\text { 产 } \\
\text { 志 } \\
\text { F }\end{array}$ \\
\hline Lemna minor L. & $\mathrm{HeSc}$ & $\operatorname{MsMgTr}$ & FHalNitrAcid & Pler & $\mathrm{Aq}$ & $\frac{3 \mathrm{ACCT \Pi}}{3 \mathrm{AC}}$ & голар. Палео \\
\hline Lemna trisulca L. & $\mathrm{HeSc}$ & MgMsTr & FHal Nitr & Hyer & $\mathrm{Aq}$ & $\frac{\text { ЗАССтП }}{\text { ЗАССтП }}$ & голар. Палео \\
\hline $\begin{array}{l}\text { Spirodela polirrhyza (L.) } \\
\text { Schleid. }\end{array}$ & $\mathrm{He}$ & $\operatorname{MgTr}$ & FHal & Pler & $\mathrm{Aq}$ & $\underline{3 \mathrm{~A}}$ & голар. Палео \\
\hline $\begin{array}{l}\text { Wolffia arrhiza (L.) Horkel } \\
\text { ex Wimm. }\end{array}$ & $\mathrm{He}$ & $\mathrm{MgTr}$ & Dul & Pler & $\mathrm{Aq}$ & $\underline{3 \mathrm{~A}}$ & голар. Палео \\
\hline $\begin{array}{l}\text { Lentibulariaceae } \\
\text { Utricaria vulgaris } L \text {. }\end{array}$ & $\mathrm{Sc}$ & $\mathrm{OgMgTr}$ & Dul & Hyer & $\mathrm{Aq}$ & $\frac{\mathrm{A}}{\mathrm{A}}$ & голар. Др.ср. \\
\hline $\begin{array}{l}\text { Najadaceae } \\
\text { Najas marina L. }\end{array}$ & $\mathrm{He}$ & $\mathrm{MsTr}$ & FHal & Hyr & $\mathrm{Aq}$ & $\underline{3 \mathrm{~A}}$ & біпол. \\
\hline $\begin{array}{l}\text { Caulinia minor (All.) } \\
\text { Coss.et Germ. }\end{array}$ & $\mathrm{He}$ & $\mathrm{MsTr}$ & Bas. Neit & Hy er & $\mathrm{Aq}$ & $\underline{3 \mathrm{~A}}$ & Косм. \\
\hline $\begin{array}{l}\text { Nymphaeaceae } \\
\text { Nuphar lutea (L.)Smith }\end{array}$ & $\mathrm{He}$ & $\mathrm{MsTr}$ & Dul & Plr & $\mathrm{Aq}$ & $\frac{3 \mathrm{~A}}{3 \mathrm{~A}}$ & євраз. др.ср. \\
\hline Nymphaea alba L. & $\mathrm{He}$ & $\mathrm{MgTr}$ & Dul & Plr & $\mathrm{Aq}$ & $\frac{3 \mathrm{~A}}{3 \mathrm{~A}}$ & паневр \\
\hline $\begin{array}{l}\text { Poaceae } \\
\text { Glyceria maxima (C.Hartm.) } \\
\text { Holub. }\end{array}$ & $\mathrm{HeSc}$ & $\operatorname{MsMgTr}$ & Dul & Hel & $\mathrm{Aq}$ & $\frac{3 \mathrm{AC \Pi}}{3 \mathrm{AC \Pi}}$ & голар. з.др. ср \\
\hline $\begin{array}{l}\text { Phragmites australis (Cav.) } \\
\text { Trin.ex Steud. }\end{array}$ & $\mathrm{HeSc}$ & $\mathrm{MsTr}$ & FHal & $\mathrm{He}$ & $\mathrm{Aq}$ & $\frac{3 \mathrm{ACCTB}}{3 \mathrm{ACC} \mathrm{B}}$ & косм. \\
\hline $\begin{array}{l}\text { Polygonaceae } \\
\text { Persicaria amphibia (L.) } \\
\text { Delarbre }\end{array}$ & $\mathrm{He}$ & OgMsTr & Hal & Plr & $\mathrm{Aq}$ & $\frac{3 \mathrm{ACT}}{3 \mathrm{ACT}}$ & ц.пол. \\
\hline $\begin{array}{l}\text { Potamogetonaceae } \\
\text { Potamogeton } \\
\text { berchtoldii Fieb. }\end{array}$ & $\mathrm{HeSc}$ & MsMgTr & Dul & Hyr & $\mathrm{Aq}$ & $\underline{3 \mathrm{~A}}$ & косм. \\
\hline Potamogeton compressus L. & $\mathrm{HeSc}$ & $\operatorname{MsMgTr}$ & Dul & Hyr & $\mathrm{Aq}$ & $\frac{3 \mathrm{~A}}{3 \mathrm{~A}}$ & євраз. др.ср. \\
\hline Potamogeton crispus L. & $\mathrm{HeSc}$ & $\operatorname{MsMgTr}$ & FHalCa & Hyr & $\mathrm{Aq}$ & $\frac{3 \mathrm{ACCT}}{3 \mathrm{ACC} T}$ & голар. пал.тр \\
\hline Potamogeton lucens L. & $\mathrm{He}$ & $\operatorname{MsMgTr}$ & Dul & Hyr & $\mathrm{Aq}$ & $\frac{3 \mathrm{~A}}{3 \mathrm{~A}}$ & євраз. др.ср. \\
\hline Potamogeton natans $L$. & $\mathrm{HeSc}$ & $\operatorname{MsMgTr}$ & Dul & Plr & $\mathrm{Aq}$ & $\frac{3 \mathrm{~A}}{3 \mathrm{~A}}$ & косм. \\
\hline Potamogeton pectinatus L. & $\mathrm{He}$ & $\mathrm{OgMg}$ & Hal & Hyr & $\mathrm{Aq}$ & $\frac{\text { 3АССтП }}{\text { ЗАССтП }}$ & косм. \\
\hline Potamogeton perfoliatus L. & $\mathrm{He}$ & $\operatorname{MsMgTr}$ & Dul & Hyr & $\mathrm{Aq}$ & $\frac{3 \mathrm{ACCT}}{3 \mathrm{ACCT}}$ & косм. \\
\hline $\begin{array}{l}\text { Potamogeton sarmaticus } \\
\text { Maemets. }\end{array}$ & $\mathrm{He}$ & $\operatorname{MgTr}$ & Dul & Hyr & $\mathrm{Aq}$ & $\underline{3}$ & з.др. ср. \\
\hline $\begin{array}{l}\text { Primulaceae } \\
\text { Hottonia palustris } L \text {. }\end{array}$ & $\mathrm{HeSc}$ & $\operatorname{MgTr}$ & Dul Nitr & Hy & $\mathrm{Aq}$ & $\frac{3 \mathrm{~A}}{\mathrm{~A}}$ & європ. в.др. ср \\
\hline $\begin{array}{l}\text { Ranunculaceae } \\
\text { Batrachium circinatum } \\
\text { (Sibth.)Spach }\end{array}$ & $\mathrm{HeSc}$ & $\operatorname{MsMgTr}$ & FHal & Hy $r$ & $\mathrm{Aq}$ & $\underline{3 \mathrm{~A}}$ & європ. з.др. ср \\
\hline $\begin{array}{l}\text { Batrachium trichophyllum } \\
\text { (Chaix) Bosch }\end{array}$ & $\mathrm{HeSc}$ & $\operatorname{MgTr}$ & Dul & Hyr & $\mathrm{Aq}$ & $\frac{\text { 3АССтП }}{\text { ЗССтП }}$ & європ. з.др.ср \\
\hline $\begin{array}{l}\text { Ricciaceae } \\
\text { Riccia fluitans } \boldsymbol{L} \text {. }\end{array}$ & $\mathrm{HeSc}$ & $\operatorname{MsMgTr}$ & FHal & Pler & $\mathrm{Aq}$ & $\frac{3 A}{3}$ & ц.бор \\
\hline $\begin{array}{l}\text { Ricciocarpus natans (L.) } \\
\text { Corda }\end{array}$ & $\mathrm{HeSc}$ & MsMgTr & FHal & Pler & $\mathrm{Aq}$ & $\underline{3}$ & ц.бор \\
\hline $\begin{array}{l}\text { Ruppiaceae } \\
\text { Ruppia maritima L. }\end{array}$ & $\mathrm{ScHe}$ & AlkTr & Hal & Hd & $\mathrm{Aq}$ & $\underline{\mathrm{C}}$ & Плюр. \\
\hline $\begin{array}{l}\text { Salviniaceae } \\
\text { Salvinia natans (L.) All. }\end{array}$ & $\mathrm{HeSc}$ & $\mathrm{MgTr}$ & Dul & Plr & $\mathrm{Aq}$ & $\frac{3 \mathrm{~A}}{3 \mathrm{~A}}$ & голар др ср \\
\hline
\end{tabular}


Закінчення табл.

\begin{tabular}{|c|c|c|c|c|c|c|c|}
\hline Види в межах родин & 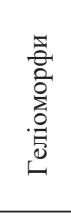 & 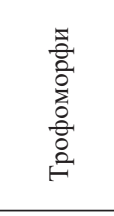 & 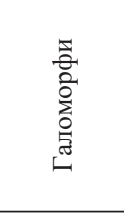 & 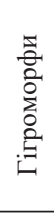 & 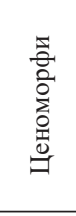 & 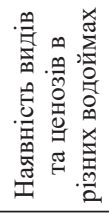 & 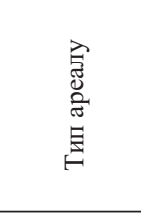 \\
\hline $\begin{array}{l}\text { Sparganiaceae } \\
\text { Sparganium erectum L. }\end{array}$ & $\mathrm{HeSc}$ & $\operatorname{MsTr}$ & FHal & $\mathrm{Hel}$ & $\mathrm{Aq}$ & $\frac{3 \mathrm{~A}}{3}$ & євраз др ср \\
\hline Sparganium minimum Wallr. & $\mathrm{HeSc}$ & $\operatorname{MsTr}$ & Dul & Hel & PalAq & $\frac{3 \mathrm{~A}}{3}$ & голар \\
\hline $\begin{array}{l}\text { Typhaceae } \\
\text { Typha angustifolia L. }\end{array}$ & $\mathrm{He}$ & MsMgTr & FHal & $\mathrm{Hel}$ & $\mathrm{Aq}$ & $\frac{3 \mathrm{ACCT}}{3 \mathrm{ACCT}}$ & косм. \\
\hline Typha latifolia L. & $\mathrm{He}$ & OgMsTr & DulNitr & Hel & $\mathrm{Aq}$ & $\frac{3 \mathrm{ACCT}}{3 \mathrm{ACCT}}$ & косм. \\
\hline Typha laxmannii Lepech. & $\mathrm{He}$ & $\operatorname{MsTr}$ & FHal Nitr & Hel & $\mathrm{Aq}$ & $\frac{3 \mathrm{C}}{3 \mathrm{C}}$ & євраз. \\
\hline $\begin{array}{l}\text { Zannicheliaceae } \\
\text { Zannichelia palustris L. }\end{array}$ & $\mathrm{HeSc}$ & $\operatorname{MgTr}$ & Hal & Hy & $\mathrm{Aq}$ & $\frac{\mathrm{CC}_{\mathrm{T}} \Pi}{\mathrm{CС}_{\mathrm{T}} \Pi}$ & косм. \\
\hline
\end{tabular}

Умовні позначки: гігроморфи: $\mathrm{Hg}$ - гігрофіти (вологолюбиві), Hel - гелофіти (повітряноводні), Pl - плейстофіти (з плаваючими листями), Ну - гідатофіти (занурені), r - укорінені, er - невкорінені. Трофоморфи: $\mathrm{Og} \operatorname{Tr}$ - оліготрофи, $\mathrm{Ms} \mathrm{Tr}$ мезотрофи, $\mathrm{MgTr}$ - мегатрофи. Геліоморфи: $\mathrm{He}$ - світлолюбиві, $\mathrm{Sc}$ - тіньовиносливі. Галоморфи: Dul - дульцифіли - рослини прісних водойм; Hal - рослини засолених водойм, Ас - асцидофіли - рослини водойм з низьким $\mathrm{pH}, \mathrm{Ca}$ - кальцефіли, Nitr - рослини водойм 3 підвищеним вмістом нітрогену; F - факультативний. Ценоморфи: Aq - акванти - водні, Pal. - палюданти - болотні.

Типи водойм: 3 - заплавні озера, A - аренні озера, C - озера солончакової тераси, Ст - ставки, П - просадочні водойми, В - відстійники.

Типи ареалу: голар. - голарктичний, косм. - космополітний, євраз. євроазійський, др. ср. - древньосередземноморський, плюр. - плюризональний, ц.бор. - центрально-бореальний, європ. - європейський, пал.тр. - палеотропічний, біпол. - біполярний.

Жирним шрифтом виділено рідкісні та зникаючи види.

Найбільше видове та ценотичне різноманіття характерне для заплавних (51 вид) та аренних (38 видів) озер, як водойм з незначним антропогенним впливом та малим ступенем трансформації. Мінімальний рівень різноманіття характерний для просадочних (10 видів) водойм та відстійників шахтних вод (2 види). Серед рослин, що утворюють ценози, найбільша кількість у заплаві (39 видів) та арені (26 видів). В озерах солончакової тераси та штучних озерах майже усі види утворюють ценози.

Ареалологічний аналіз показав, що більшість водних рослин, майже в рівній кількості, належать до євроазійського (15), голарктичного (14) типів ареалу, або $\epsilon$ космополітами (12).

Висновки. Таким чином, заплавні та аренні озера Присамар'я відрізняються великим різноманіттям видового та ценотичного складу рослинності за рахунок мінімального антропогенного впливу i, в першу чергу, - збереження великого лісового масиву. Їх можна вважати генофондом рідкісних та зникаючих видів рослин водойм Степового Придніпров’я.

\section{Бібліографічні посилання}

1. Акинфиев И. Я. Ботанические исследования Новомосковского уезда Екатеринославской губ. // Материалы к познанию фауны и флоры Российской импер., изд. Московским о-вом испыт. прир. отд. бот.: 1896. Вып. 3. С. 1-24.

2. Акинфиев И. Я. Ботанический очерк Новомосковского уезда // Материалы по оценке земель Екатеринославской губернии. Екатеринослав. 1908. С. 1-15. 
3. Растительный и почвенный покров Присамарья Днепровского / Ю.Е. Алексеев и др. Днепропетровск. 1986. 63 с.

4. Альбицкая M. $\boldsymbol{A}$. Опыт флористического анализа присамарских арен // Сб. биол. ф-та ДГУ. Днепропетровск. 1948. С. 27.

5. Барановский Б. А., Бондаренко Л. В. Современная находка Aldrovanda vesiculosa L. в Присамарье // Проблеми фундаментальної екології: матеріали II Всеукраїнської конф. Кривий Ріг. 1998, С. 39-42.

6. Барановский Б. A. Флора водоемов бассейна р. Самары // Питання степового лісознавства та лісової рекультивації земель: зб. наук. праць. 2002. С. 90-103.

7. Барановский Б. А. Растительность пойменных водоемов Присамарья Днепровского // Питання степового лісознавства та лісової рекультивації земель: зб. наук. праць. Вип. 9 (34). 2005. С. 90-94.

8. Барановський Б. О. Знахідка Ruppia maritima L. (Ruppiaceae) у континентальних водоймах України // Укр. ботан. журн. 2011. Т. 68. № 2. С. 208-211.

9. Барановский Б. А., Волошина Н. О. Фиторазнообразие раритетной флоры водной и прибрежной флоры водоемов северного степного Приднепровья // Питання степового лісознавства та лісової рекультивації земель: зб. наук. праць. Вип. 12 (38). 2011. С. 69-76.

10. Бельгард А. Л. Лесная растительность юго-востока УССР. Киев. 1950. 258 с.

11. Бельгард О. Л. Геоботанічний нарис Новомосковського бору // Зб. робіт біол. ф-ту. Наук. зап. Дніпропетр. ун-ту. 1938. С. 107-132.

12. Визначник рослин України. Київ. 1965. 876 с.

13. Віленський Д. Про нову знахідку на Україні Ceratophyllum tanaiticum Sapeg. // Тр. с-г. ботаніки. - Харків. 1927. Т. 1. Вип. 3. С. 83-87.

14. Волошина Н. О. Порівняльний аналіз флори озер долини Самари в районі Присамарського біосферного стаціонару // Вісник Харків. нац. ун-ту ім. Каразіна. №1100. 2014. C. 235-241.

15. Дем'янов В. В. Гідрологічна характеристика басейну р. Самара // Питання степового лісознавства та лісової рекультивації земель: зб. наук. праць. 2010. С. 67-79.

16. Еліашевич О. Матеріали до флори долини р. Самари. // Тр. сільсько.-госп. бот. Харків. 1927. Т. І. В. 3. С. 78-82.

17. Катанская В. М. Высшая водная растительность континентальных водоемов СССР. Ленинград. 1981. 185 с.

18. Котов М. И. Ботанико-географический очерк низовьев реки Самары // Тр. Гос. ихтиол. опытной станции. Херсон. 1930. T.VI. Вып. І. С. 57-99.

19. Определитель высших растений Украины. Киев. 1987. 545 с.

20. Скворцов A. К. Гербарий : пособие по методике и технике. М. 1977. 200 с.

21. Тарасов В. В., Алексеев Ю. А., Губанов И. А. Растительные ресурсы Присамарья Днепровского. $1988.68 \mathrm{c.}$

22. Тарасов В. В., Барановский Б. А. Дополнение к флоре Присамарья //Питання степового лісознавства та лісової рекультивації земель: зб. наук. праць. 2003. Вип. 7. С. 92.

23. Tарасов B. В. Флора Дніпропетровської та Запорізької областей. Судинні рослини // Біолого-екологічна характеристика видів. Дніпропетровськ. 2005. 276 с.

24. Травлеев А. П. Материалы к номенклатуре и классификации лесных почв подзоны настоящих степей // Вопросы степного лесоведения: Тр. Комплексной экспедиции ДГУ. 1972. Вып. 3. С. 16-22.

25. Физико-географическое районирование Украинской ССР. Киев. 1968. 684 с.

26. Флора европейской части СССР // под ред. А. А. Федорова. Ленинград. 1974 1989. T. I-VIII.

27. Флора УССР. Киев. 1935-1965. Т. І-ХІІ.

28. Червоний список видів рослин і тварин Дніпропетровської області, затверджений рішенням обл. ради депутатів 27.12.2011 № 219-10/VI). 27 с.

29. Mosyakin S. L., Fedorochuk M. M. Vascular plants of Ukraine // Nomenclatural checklist. Kuyiv. 1999. 346 c.

Надійшла до редколегії 09.08.2016 p. 